\title{
遺伝的アルゴリズムを用いたトラス構造物の形態創出 FORM CREATION OF TRUSS STRUCTURES BY GENETIC ALGORITHM
}

\author{
大森博司*, 鬼頭伸 彰** \\ Hiroshi OHMORI and Nobuaki KITO
}

\begin{abstract}
Many works have been already published until today on the structural optimization of truss topology using the genetic algorithms. In most cases these works express the truss topology as a combination of members, and existence of each member is directly connected to the genetic code. These methods, however, have a fatal weak point. Namely when the topology is made along these methods, they might include needless members or those which lies on the other members. In addition to these problems, generated structures are not always given as a stable structure. These problems become more remarkable when the freedom of the problem becomes large.

A new method is proposed in the present paper resolving those problems by expressing the truss topology as a combination of triangles which are joined each other. Detail of the proposed methodology is pi $\epsilon$ sented as well as the results of numerical examples which clearly show effectiveness and efficiency of the present method.
\end{abstract}

Keywords: topology optimization, genetic algorithm, structural optimization, nonlinear l'rogramming 位相最適化、遺伝的アルゴリズム、構造最適化、非線形計画法

\section{1. 研究の目的}

構造力学は従来より主として与えられた構造物の与えられた荷重に 対する応答の理論的予測の手段として用いられてきた。所与の力学的 条件に対する解析結果を検討し、要求基準を満足しない場合には初期 の条件を変更して再度解析を行い、要求基準が満足されるまでこの順 解析の過程を繰り返すのが通常の設計手順である。しかし、そもそも 構造物の設計とは、与えられた空間条件と力学的条件に適合する構造 物を創造することと考えることができ、与えられた設計条件を所与の 条件とし、その結果として構造物を得るのが本来の手順である。この ように、設計という観点からみるとむしろ、従来逆解析と呼ばれてい る手順こそを、順解析と呼ぶべきであることがわかる。

構造物を設計するに当たってはまず、ラーメン、トラス、アーチ、 ケーブル、膜、板、シェルあるいはそれらの複合形といった、極めて 多種類の中から採用する構造形式を選択し、次いで構造の形状を決定 し、その上で各部材の断面を決定するという手順を踏む。構造形式や 形状決定に関わる初期の過程のほとんどは、設計者の経験や勘あるい は好みといった定量的な記述の困難なものによって進められる。通常 の設計ではこれらの準備ができたところで設計外力が定められ、これ による構造物の応答を推定する手段として構造力学が利用されるに過 ぎない。断面算定という表現は、限定された構造形式・形状による、
限られた狭い範囲内での断面汒定を目指した順的な䆆り返し計算を指 している。構造力学が設計というステージを縁の下から支えるとされ る所以がここにある。これに対して前述の逆解析は、荷重条件を与え、 確保すべき空間に関する制限を与え、これらを満たす構造形式や形状 を直接に見いだす解析過程を指している。本論文の表題の「形態創出」 という言葉はその過程を表わしたものである。

一方、従来より構造最適仳問題として扱われてきている種々の研究 の対象とするところは、数学的に表現された所与の条件を満たす解の 中から、重量、ひずみエネルキー、振動数などを最適なものにする問 題である。主に機械工学の分里:で発展したこれらの研究成果を、構造 物の設計過程に「部品」として用いることを考えれば、構造設計の相 当の部分に理論的手法を導八することができると考えられる。

構造最適化問題は、寸法決足㵍題と位相決定問題とに分けられ、前 者には部材断面や大きさ、さらには構造形状の決定を目的とする問題 もこれに含まれるのに対して、後者はトラスやラーメンの部材の結合 形式、さらには構造形式をも含んた構造物全体の「かたち」の決定を 目的としたものである。寸法決定問題は、所与の初期解近傍に前述の 重量やひずみエネルギーといったスカラー関数を停留させる解を求め る非線形計画問題に帰着され、感度情報に基づく逐次的近似解析によ り目的解を得ることができるものがほとんどである。一方、位相決定
* 名古屋大学工学研究科建築学専攻 助教授. 工博

** 陎伊藤建築設計事務所 工修
Assoc. Prof., Dept. Architecture, Nagoya Univ., Dr. Eng. Itoh Architectural Design Office Co., Ltd., M. Eng. 
問題は、離散的な線材である場合には部材数や節点数、連続体であれ ば、つまるところ単連結か多連結か、多連結であればその連結数を求 めることが目的となり、問題は本質的には離散变数により構成される 整数計画問題を解くことに帰着される。この整数計画問題を系統的に 解く一般的方法としては分枝限定法が代表的なものとしてあげられる が、問題の規模が大きくなるにつれて演算量が急に大きくなり、解く ことは事実上不可能となる。前述の逆解析過程では、寸法決定問題と 位相決定問題の双方の問題を解くことが必要となり、特に構造形式の 決定を理論的に行おうとする際には解くことが困難とされる構造位相 の決定方法の導入が不可欠になる ${ }^{1)}$ 。

本研究は、構造形式と構造形状を、所与の設計条件に基づいて決定 したり、設計条件を満たす構造システムを提案できる一連の解析過程 を考案することを最終的な目的としたもので、本論文はそのための基 碳研究のひとつとして、簡単なトラス構造を対象とした構造システム の提案過程を実現する遺伝的アルゴリズムを利用した手法について述 ベたものである。

\section{2. 既往の研究と本論文の位置つけけ}

ここでは、対象をトラス構造に限定して議論する。前章で述べたよ うに本来は、構造形式の選択の一つの結果としてトラス構造が選択さ れることになる。したがってここでの議論は前章で記述した逆解析の 流れにおいては、構造形式としてすでにトラスが選択された後の議論 になる。

平面トラスの部材断面積を最適化の対象とする研究には非常に多く のものがある。これは前節で述べた寸法決定問題で、部材の断面積を 最適化の変数とした通常の感度解析に基づいた方法が有効であり、既 に線形計画法や非線形計画法を用いた構造解析プログラムも市販され ている。また、トラスの形状の最適化に関する研究については、トラ スの節点座標を変数としたものが多ぐ、最近では単に形状を最適化 するだけではなく部材やユニットの統一性を考虑することによる施工 の容易性を解析過程に取り入れる工夫も提案されているすこれらの 研究はいずれも前述の寸法決定問題に属するものである。

これに対して、トラスの部材数や節点数そのものを対象とし、それ らの組み方を解として求める位相決定問題の解析法に関する研究は、 その困難さにもかかわらずすでに歴史は古く、線形計画法に基づく Domらの研究 ${ }^{\natural}$ に始まり、部材の座屈を拘束条件として考慮した Dobbsらの研究? も既に1960年代に行われている。これらは対象を低自 由度のトラスに限定したものとしているものの、位相決定に関する研 究に端緒を与える優れた研究である。そこでは、あらかじめ対象とす る空間に規則的な固定節点を置き、それらの節点間を結合する直線の 組み合わせの問題としてトラスの位相を決定しようとするグランドス トラクチャー法と呼ばれる方法が用いられており、これは非常に素直 な解析手法で、汎用性も高いが、問題を単純な組み合わせ問題に帰着 させるため、何らの工夫も用いずに扱った場合、節点数の増加ととも に末知量が爆発的に増加し、少し大きなモデルになると解くことは事 実上不可能となってしまう。着想のすばらしかったこれらの研究が改
良の余地を多分に残したまま、その成果を継承する硂究がその後ほと んど見られないのも、こうした障壁を乗り越える手法を見つけること が困難であったことが大きな㼂由であると考えられる。その後、均質

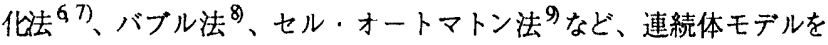
出発点として贅肉をそぎ落とすことにより結果として最適骨組構造を 得ようとする方法、トラスの部材配置を閉じたループの集合として扱 う境界輪体法 ${ }^{10)}$ などの方法が提案されている。いずれも興味深い方法 ではあるが、前者の連続体モデルでは、計算に膨大な労力を要すると ともに、消失要素の再生方法に共通の問題があり、後者の特殊な工夫 による方法はそのままでは3次元に適用できないという問題点を持つ。 ところが、80年代に入って整数計画法の一解析手法として、遺伝的 アルゴリズム(GA、以下同じ)と呼ばれる手法がHollandによって考案 され、Gold berg ${ }^{11)} に よ っ て$ 化学プラントのパイプの敷設の最適化問題 に適用されて成功して以来、その有効性が広く認識されるようになっ た。その後、工学問題の広い範囲でこの手法が利用されるようになり、

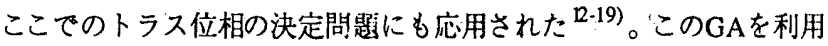
したトラスの構造最適化問題を扱った研究には、トラス節点のコスト を勘案したコスト最小化について扱った研究 ${ }^{16)}$ や規格化された部材を 選択対象とした重量最小化問题を扱った研究"があるが、中でも Hajelaの研究 ${ }^{15)}$ はトラスの位相決定をGAを用いて正面から扱った最初 の研究で、それまで全く手のつけられていなかった組み合わせ問題と してのトラス位相の解析に道を開いた意義はきわめて大きい。

トラス位相の決定には現在のところ上述のHajelaの研究に見るよう な、グランドストラクチャーと呼ばれる、空間に置かれた節点群間を、 如何に結合して所望のトラスを得るかと言う問題を整数計画法の問題 として解く方法が直接的で有効な手法であると考えられる。本論では この手法をより効果的で実際的なものにするためのいくつかの新しい 提案を行い、さらに位相決定だけでなく形状や部材断面をも同時に最

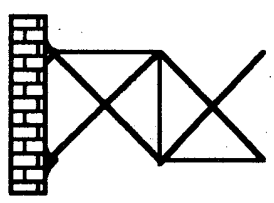

不必要な部材

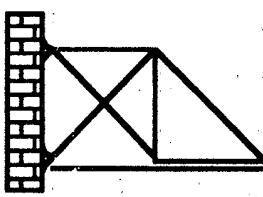

部祆の重なり

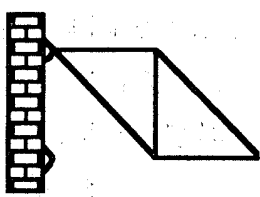

不安定な構造
図1: 不安定・不合理なトラスの例

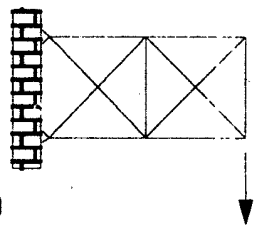

Ground Structure

$\mathrm{nx}:$ 水平方向節点数

ny : 鉛直方向分割数

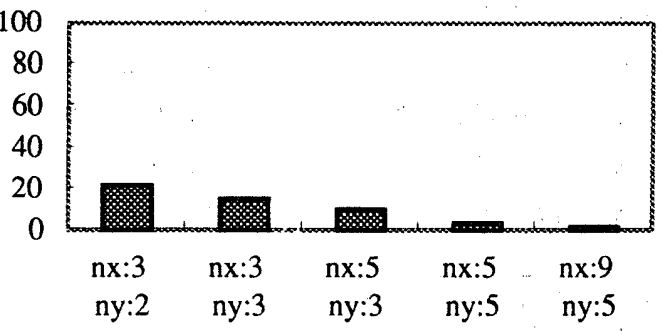

凮2: 安定構造の発生確率 
適化するための方法について提案し、解析例を示してそれらの有効性 を示すとともに、提案する手法の今後の可能性について検討を行なっ ている。

\section{3. 解析手法}

3.1 構造的安定要妻を用いた遺伝的アルゴリズム

トラスの位相決定を遺伝的アルゴリズムを用いて解析しようとする 場合、まずトラスの形状を計算機が認識できる形に表現する必要があ る。前述のようなグランドストラクチャー法に基づいて形状表現を行 う際には、接続可能な節点間の部材の有無を染色体のビット列として 表現するのが素直な方法である。その際、節点の選択はそれにより表

口部材の組み合わせによる表現

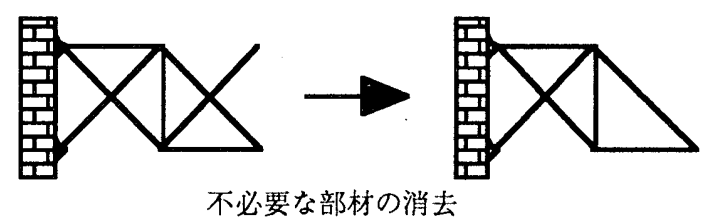

口三角形要素による表現
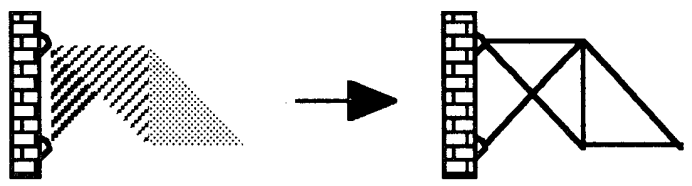

三角形の辺の部材表現への置き換え

図3: 三角形を基準要素とした構造体の発生
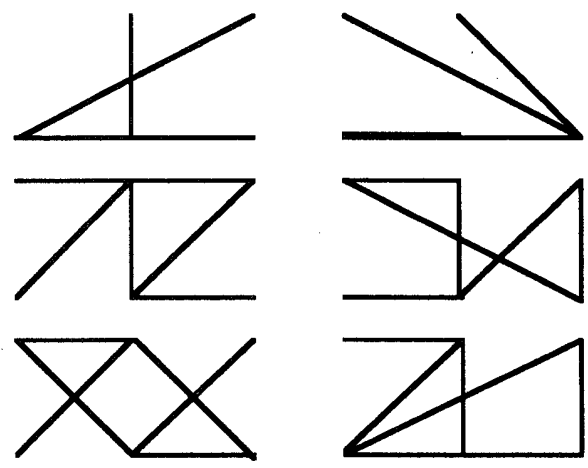

部材表現に基づいて発生した初期個体群 (P.Hajela and E.Lee, 1995)
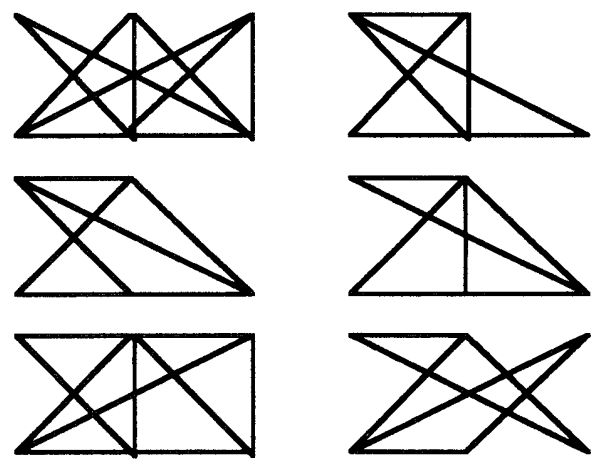

三角形表現に基づいて発生した初期個体群

図4: 部材表現と三角形要素表現による初期世代のトラス位相
現される、構造とは無縁の単なる幾何学的な図形として選択されるた め、生成された結果には部材が重複していて構造物として不都合であっ たり、構造的に不安定であったりするものが多数生成される。図1に そのような場合の例を示す。こうした不都合な例の発生する割合は対 象が大きくなるにつれて急激に顕著になり、規模の大きな構造物を対 象とする場合にはどうしても解決する必要のある問題であった ${ }^{15)}$ 。図 2 に個体数の増加に伴って構造的に意味のある個体の発生確率が減少 する様子を簡単なトラスの場合について示している。本論文ではこの 問題を、トラスを三角形などの構造的安定要素の集合と考えることで 解決している。その椂子を平面トラスの場合について図 3 に示す。

ここで、初期世代における発生構造形状について前述のHajelaらの 研究と比較してみる。図4の上図にそこで示されている初期世代の発 生形状を示す。図からもわかるように、明らかに不要な重複要素や不 安定構造となる個体が多く発生することがわかる。こうしたことは遺 伝的アルゴリズムにおける人口（個体数）が増加すればますます顕著 になり、大自由度での解析を妨げる致命的な要因となる。このような 構造として成り立たないものを淘汰する際には構造安定の判別を行っ たり、重複する要素がある場合にはこれを判断して排除する必要があ り、操作が煩雑になるばかりか、場合によっては自動的には判別しき れない場合もある。これに対して、図4の下図に示すように、本論文 で提案する方法ではこうした問題はすべて解決されることになる。

\section{2 多層型遺伝的アルゴリズムの提案}

性格の異なる二つの問題を同時に最適化することが望ましい問題が 多くある。たとえばトラスの位相と形状や断面積を同時に最適化する ような場合である。このような問題に対しては第一段階として離散量 を含む位相決定問題について解き、その結果得られる最適解やそれに 近い形状のいくつかを第二段階の初期解群として形状や断面樍につい て決定する手法を用いるのが単純な方法として考えられる。しかし、 厳密な意味ではこの方法で得られた解か深索領域内での大域的な最適 解であるという保証はない。つまり、位相、形状、さらには断面積は、 トラスの性能に対する寄与度に関して相互に相関を持って続びついて おり、どれか一つを固定して解探索を行うことは理論的には正しくな い。このような考え方に基づき、遺伝的アルゴリズムを用いて、位相 と断面積を遺伝子情報に直列にのせて解析した報告もある ${ }^{14,18,20)}$ が、 遺伝子の長さは必然的に大きなものとなり、設計变数の増加に伴う未 知数の爆発による障壁を越えることができておらず、そのままでは事 実上、解析不能となる。前述のHajelaら ${ }^{15)}$ も部材の有無に関する情報 と断面積の大きさに関する情報を同等に遺伝子上に並べてコード化し ており、大崎 ${ }^{16,21)}$ は部材の断面積を同様にビット表現し、部材の断面 積が0になる時にその部材が存在しないとする方法を用いている。こ れらの手法には一長一短があるが、いずれの手法も位相に関する情報 と断面寸法に関する情報を区別することなく扱っていることについて 本質的には同じである。本論文では性格の異なる問題を同時に扱うこ とのできる新しい遺伝的アルごリズムの手法を提案する。

ある生物の成長を考察対象とするとき、これを生物の種類と環境の 二つの観点から考える。生物の; 種類に関しては優良な個体はどのよう な環境においてもよく成長し汻汰されにくく生き残る確率は高い。通 
位相の情報

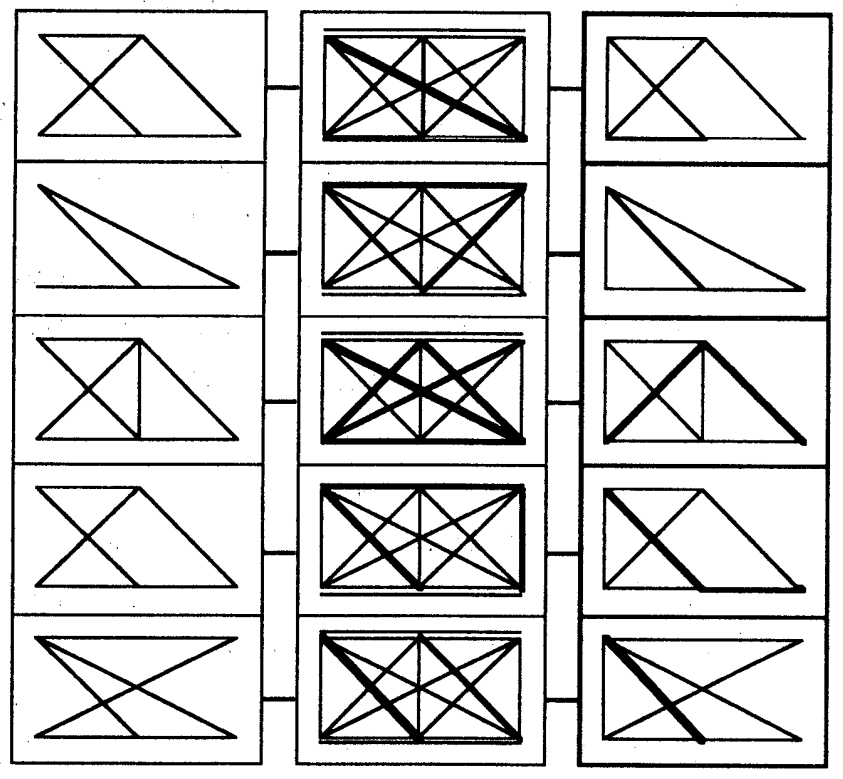

図5:「多層型遺伝的アルゴリズム」による構造表現

常の遺伝的アルコリズムはこの視点のみから考えるが、さらにこれに 環境という因子がある場合を考える。いくつかの環境下で複数回、生 物を成長させた後にある環境について注目したとき、その環境下で、 ある生物の成長が早ければ、その環境はその生物に適した環境である ことになる。逆にある環境下でその生物の成長が平均的によくない場 合、その環境はその生物の成長に適していないことになる。生物の成 長を目的とし、環境をできるだけその生物の生育に適したものにして やることが有効である場合、優良である環境を残し、そうでないもの を淘汰すること、つまり環境についても生物の個体と同様に選択、交 叉、評価を行う方法を考えるのである。この手法を、「多層型遺伝的 アルゴリズム（多層型GA、Layered GA）」と呼ぶことにする。ここ て提案する遺伝的アルゴリズムの基本的な考え方を位相と部材断面を 共に最適化する平面トラスの場合について図示すれば図5のようにな る。

\section{3 コーディング}

汶6から図8に初期発生、交叉、突然変異の過程を、3.1節で示した 三角形要素に基づいて遺伝的アルゴリズムのコーディングを行った際 の様子を示している。初期発生は図6に示すように三角形を基本とし て形状を発生させ、荷重点か境界点から出発し、それらのいずれもが 含まれるようになるまで三角形の発生を繰り返すことによって得る。 交叉と突然变異はそれぞれ図7 と図8 に示すように、三角形が成立す る部分で遺伝子の切断を行う点が通常のGA と異なる点となる。トラ スへの置換は、このようにして得られた構造的安定要素の集合の各辺 を線材に置き換えることにより行う。

また、多層型遺伝的アルゴリズムは、例えば位相と断面積を同時に 扱う場合、それぞれ指定された個体数分だけ初期発生させ、断面積の 個体群をそのまま固定し、位相の遺伝子だけを進化させ、一定の進化 が進んた段階まで、二つの遺伝子群の重ね合わせで表現することによ り得られる個体の適合度を連続的に評価し、その結果を平均して得ら れる平均適合度に基づいて断面積の遺伝子に選択 · 交配 ·突然変異の
初期発生

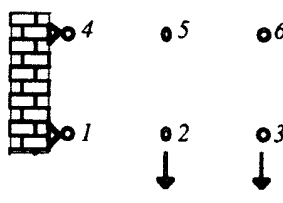

Phase 1

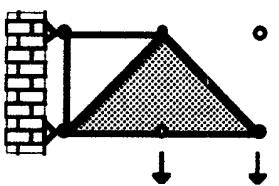

Phase 3

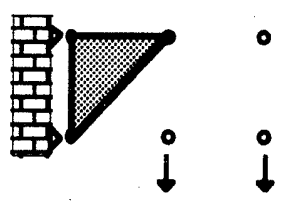

Phase 2

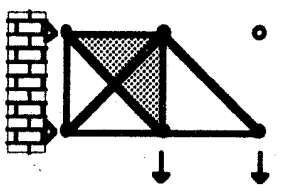

Phase 4
図6 : 安定要素による初期発生

交叉
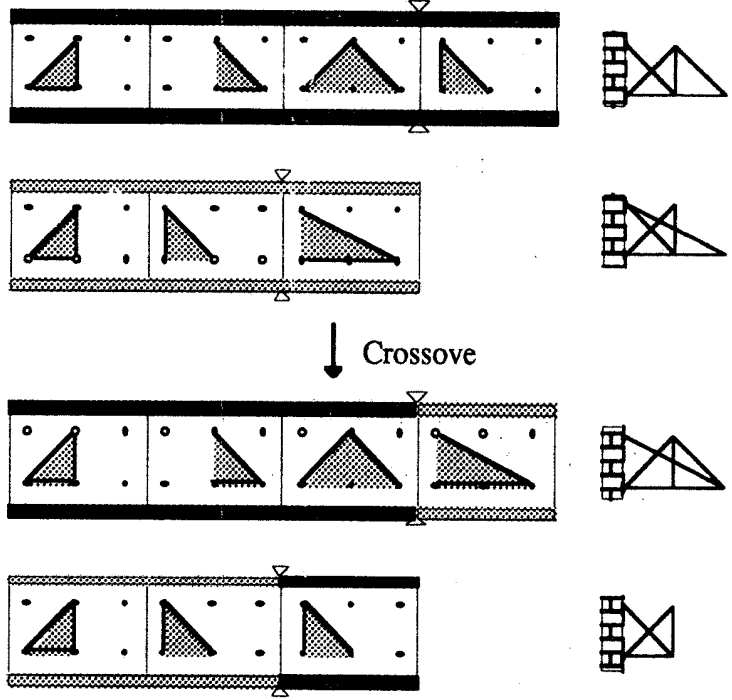

突然变異

図7 : 安定要素による交叉
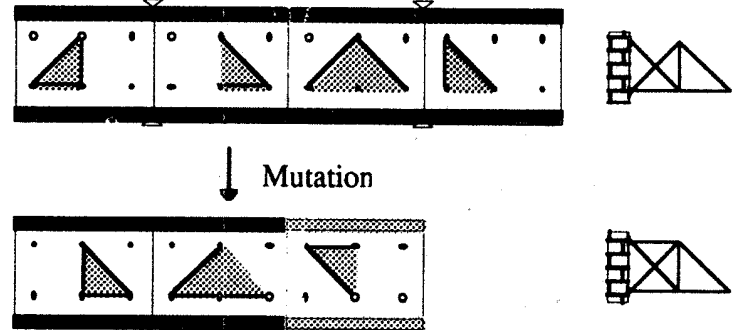

図8 : 安定要素による突然変異

過程を課すというアルゴリズムにより実現する。これにより、従来の 直列表現による場合に比べて、大幅な探索空間の削減が実現されるこ とになる。

\section{4. 問題の記述と適合度の評価}

ここでの問題は、与えられた構造応答に関する変位や軸力に関する 制約条件下で、最小重量となるトラス構造を見出す問題で、次式のよ うに表現することができる。 


$$
\begin{gathered}
W\left(\boldsymbol{x}_{i}, A_{j}\right) \Rightarrow \text { Minimum } \\
g_{k} \leq 0
\end{gathered}
$$

ここに、

\section{$W:$ 構造物の重量}

$x_{i}$ : 第 $i$ 節点の空間座標 $(i=1 \sim$ トスの全節点数 $)$

$A_{j}$ : 第 $j$ 要素の断面積（材軸方向に一定、 $j=1 \sim$ ラスの全要 素数)

$g_{k}$ : 構造応答（変位、軸応力）に関する制約条件（ $k=1 \sim$ 制 約条件数)

である。また、遺伝的アルゴリズムにおける適合度の評価は、次式で 行なう。

$$
\text { Fitness }=\frac{1}{W} \prod_{i} \gamma_{i}
$$

ここに、左辺の Finessは適合度を表わす。また、 $\gamma_{i}$ は制約条件による 低减を表わす関数で、例えば部材応力を制約条件として与えた場合の 低减関数 $\gamma_{\sigma}$ は次式のように表わされる。

$$
\gamma_{\sigma}=\left\{\begin{array}{cc}
\sigma_{\lim } / \sigma & \sigma>\sigma_{\lim } \\
1 & \text { 上記以外の場合 }
\end{array}\right.
$$

ここに、

$$
\begin{aligned}
& \sigma_{\lim }: \text { 正負を考慮した応力制限值 } \\
& \sigma: \text { 部材に実際に生じる応力の絶対值最大值 }
\end{aligned}
$$

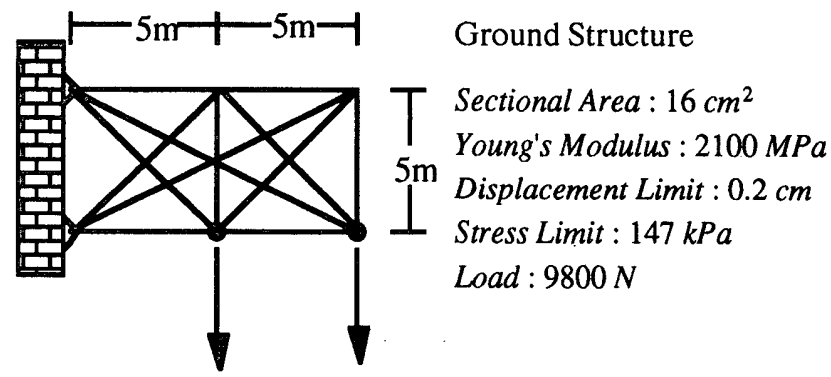

図9:片持ちトラスの問題

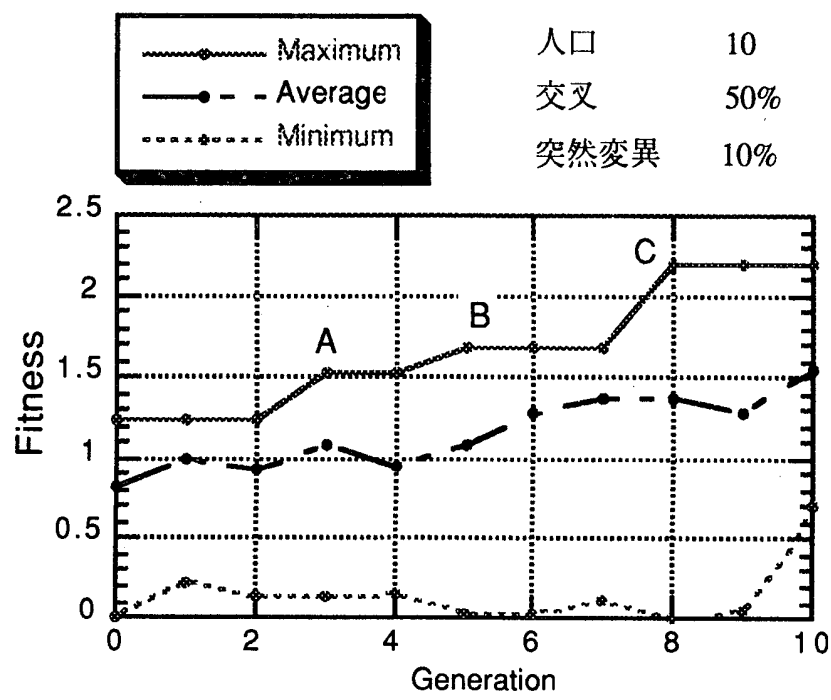

図12: 一定断面トラスのGA求解過程

Topology A

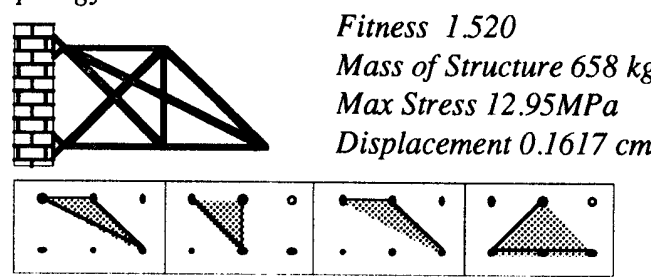

Topology B

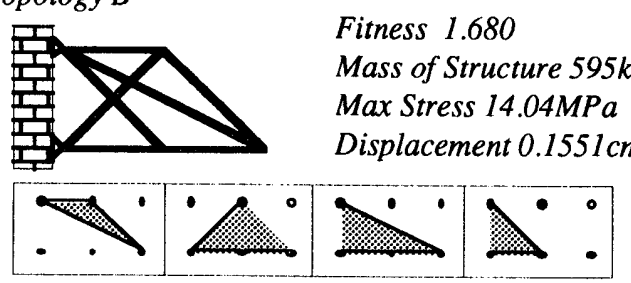

Topology C

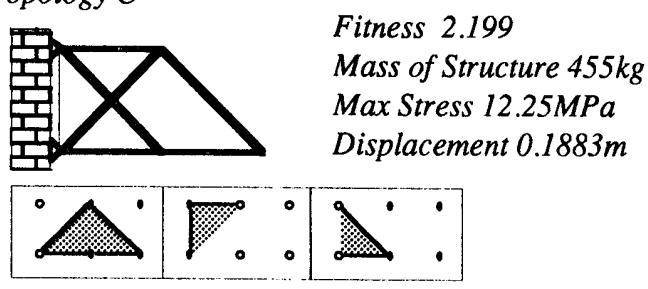

図10:片持ちトラス（一定断面）

Topology A

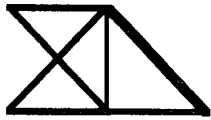

Topology B

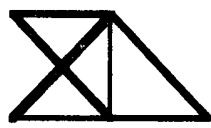

Topology C

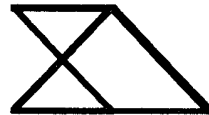

Topology D

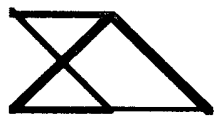

Fitness 2.103

Mass of Structure $427 \mathrm{~kg}$

Max Stress 14.13MPa

Displacement $0.2111 \mathrm{~cm}$

Fitness 2.122

Mass of Structure $471 \mathrm{~kg}$

Max Stress 13.23MPa

Displacement $0.1996 \mathrm{~cm}$

Fitness 2.359

Mass of Structure $374 \mathrm{~kg}$

Max Stress 14.00MPa

Displacement $0.2129 \mathrm{~cm}$

Fitness 2.482

Mass of Structure $403 \mathrm{~kg}$

Max Stress 13.86MPa

Displacement $0.1987 \mathrm{~cm}$

図11: 片持ちトラス（変断面）

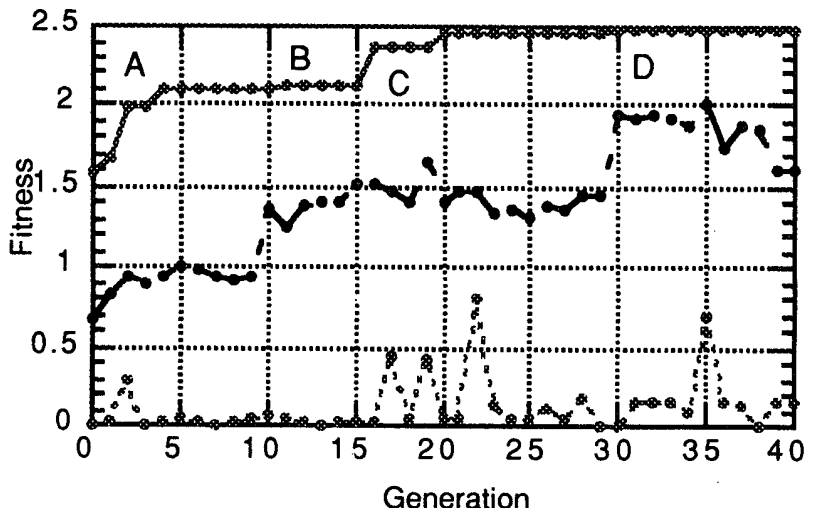

図 13 : 変断面卜ラスのGA求解過程 


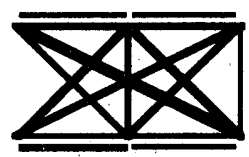

Fitness 1.069

Mass of Structure $(\mathrm{kg}) 582$

Max Stress (Mpa) 15.41

Displacement $(\mathrm{cm}) \quad 0.227$

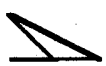

Fitness

Mass of Structure $(\mathrm{kg})$

Max Stress (Mpa)

Displacement $(\mathrm{cm})$

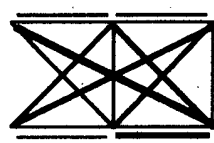

Fitness

Mass of Structure ( $\mathrm{kg})$

Max Stress (Mpa)

Displacement $(\mathrm{cm})$

445

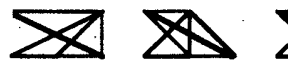

0.668

341

18.38

0.301

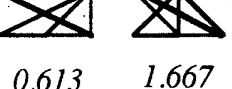

$635 \quad 600$

$0.251 \quad 0.185$
$16.92 \quad 13.13$
$\$$

1.328

753

13.21

0.169
Fitness 0.138

Mass of Structure $(\mathrm{kg}) 432$

Max Stress (Mpa) 41.52

Displacement $(\mathrm{cm}) 0.346$
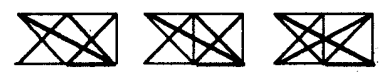

0.027

0.031

0.042

477

427

44.72

40.10

41.28

0.344

0.334

0.361

Fitness 0.908

Mass of Structure $(\mathrm{kg}) 754$

Max Stress (Mpa) 18.03

Displacement (cm) 0.175

\section{$\$$}

Fitness

Mass of Structure $(\mathrm{kg})$

Max Stress (Mpa)

Displacement $(\mathrm{cm})$

0.730

$\$$

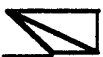

図14:多層型GAにおける位相と断面積の表現

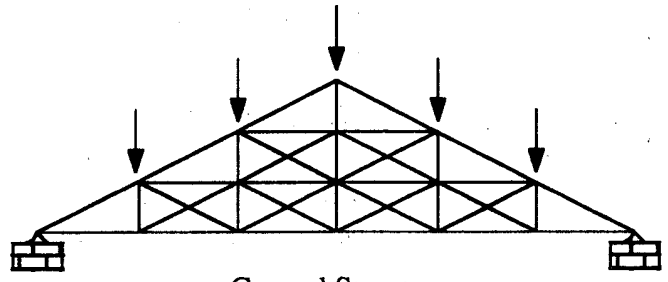

Ground Structure

Sectional Area: from 5 to $20 \mathrm{~cm}^{2}\left(\Delta=1.0 \mathrm{~cm}^{2}\right)$

Material: $E=2100 \mathrm{MPa}$

DisplacementLimit : $0.07 \mathrm{~cm}$

Stress Limit : $147 \mathrm{kPa}$

Load : $4900 \mathrm{~N}$

$-5 \mathrm{~cm}^{2}$

$20 \mathrm{~cm}^{2}$

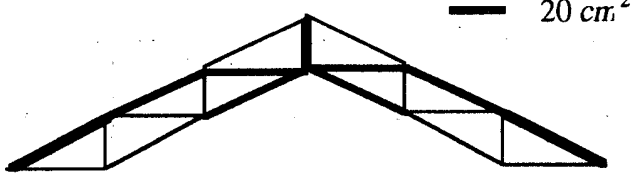

Best topology at 50th generation

Fitness : 2.977

Total Mass : 0.336 ton

Max Stress : $137 \mathrm{kPa}$

Displacement: $0.0694 \mathrm{~cm}$

図15: 山形トラスの解析

\section{5. 数值解析}

本節では数值解析例を通しで、ここで新しく導入した遺伝的アルコ リズムによる解析手法の特色とそれによって得られるトラスの構造形 態について考察を行う。

5.1 簡単なトラスの問題

図 9 14 に片持ちトラスの例を示す。これは6節点14要素のグラン ドストラクチャーによる場合で、軸応力と載荷点での鉛淔変位に上限 を持つ場合の最小重量設計解を求める問題を解いた結果を示したもの で図10に部材断面積を一定とした時、図11に部材断面積を変化させ た時の、それぞれ解形状を示している。図中トポロジーA、Bなどと あるのは、図12 およひ図13に示すGAの解析過程において適合度が順 次改良される過程で出現する解形状を図中の記号を対応させて示した ものである。さらに、図14には、ここで提案している多層型GAをこ の問題に適用した場合の位相と断面積の個体の重ね合わせによりその 段階での解が得られる様子を示したものである。図中で各数值名上の 線ば、そこに示されている数值が一定の世代間（ここでは10世代とし ている）での平均値であることを意味している。多層型GAにおける 適合度はこのように扱う変数のいずれかを固定して進化させた時の平 均值として評価する。予想されるとおり、断面積変化をも許した、自 由度の高い扱いによる場合の方が性能の高い解を示すことが分かる。 なお、ここでは断面積変化として5〜20 $\mathrm{cm}^{2}$ を $1 \mathrm{~cm}^{2}$ 刻みで16種類の部材 から選択している。図15には、同様の扱い方により山形トラスにつ いて解析した結果を示している。

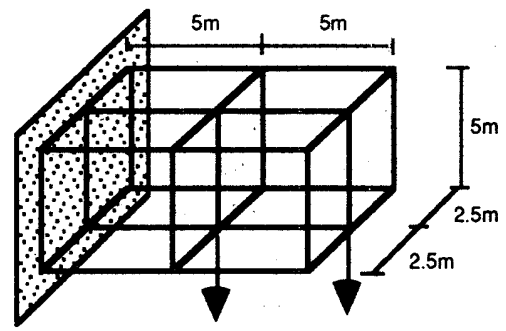

解析モデル

0.968

776

17.05

0.169

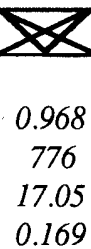

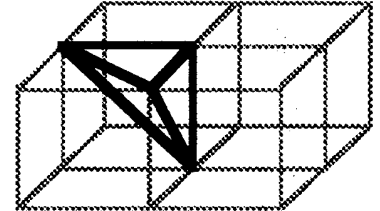

Phase 1
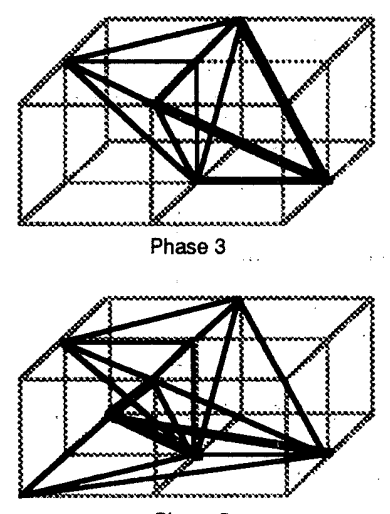

Phase 5

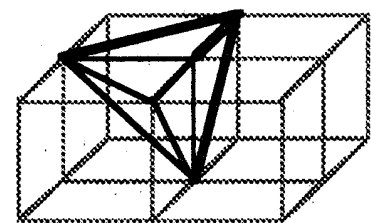

Phase 2

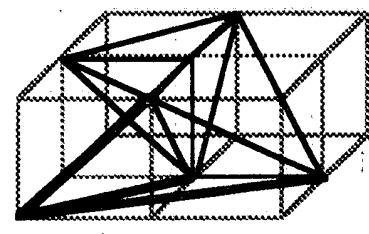

Phase 4

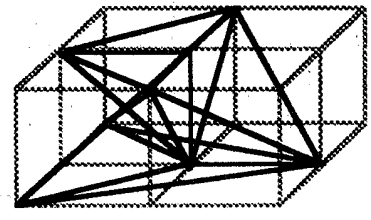

Phase 6

図16: 立体トラスの初期形状の発生 


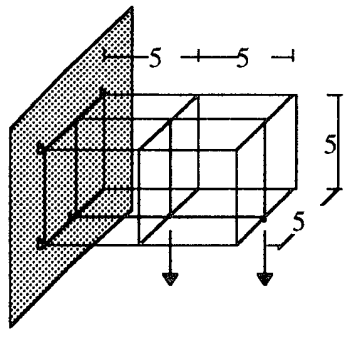

Sectional Area : 5 to $20 \mathrm{~cm}^{2}(\Delta=1.0 \mathrm{~cm}$ Young's Modulus : $E=2100 \mathrm{MPa}$

Displacement Limit : $0.2 \mathrm{~cm}$

Stress Limit : $147 \mathrm{kPa}$

Load : $9800 \mathrm{~N}$

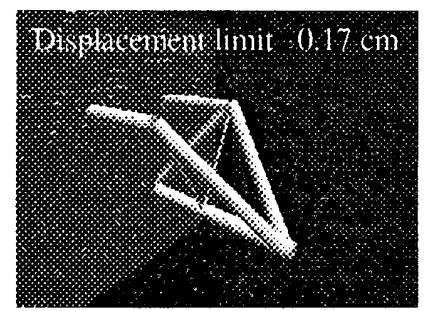

Fintness : 3.675

Mass : 0.272 ton

Max Stress : $123 \mathrm{kPa}$

Displacement : $0.1688 \mathrm{~cm}$

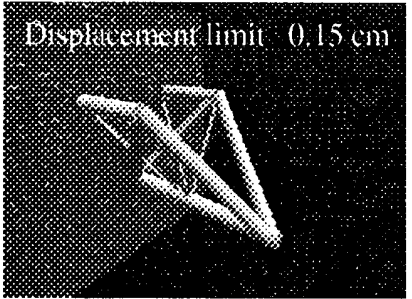

Fintness : 3.079

Mass : 0.325 ton

Displacement : $0.1466 \mathrm{~cm}$
Max Stress : $105 \mathrm{kPa}$

図17: 断面積と位相を考慮した解析

\section{2 立体トラスへの適用}

平面の問題で用いた三角形を四面体に置き換えることによって、平 面の場合と同じようにして3次元構造物への拡張が可能である。図16 に初期形状の発生の機構を示している。まず最初に四面体が発生可能 となるように選択可能領域内の4節点を任意に選択し四面体を形成す る（Phase1）。次に既に選ばれた4節点の中の任意の3節点と新たに選 択可能領域から選ばれた1節点により新しい四面体を形成する

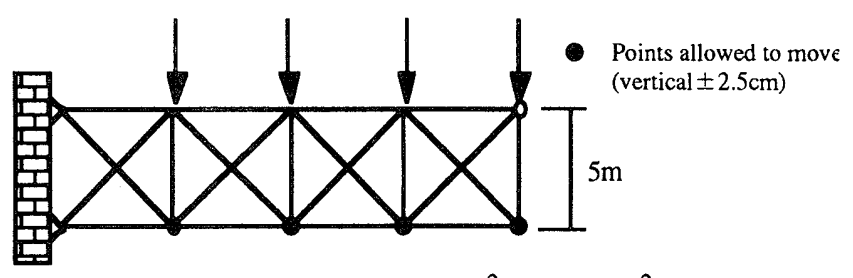

Sectional Area : from 5 to $20 \mathrm{~cm}^{2}\left(\Delta=1.0 \mathrm{~cm}^{2}\right)$

Material $: E=2100 \mathrm{MPa}$

Displacement Limit : $0.7 \mathrm{~cm}$

Stress Limit : $147 \mathrm{kPa}$

Load : $9800 \mathrm{~N}$

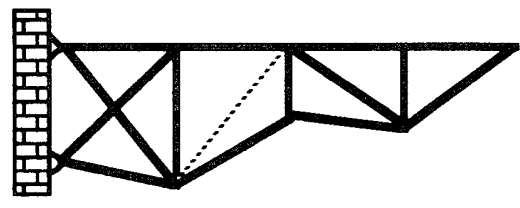

Fitness : 0.811

Total Mass : 1.186 ton

Max Stress : $149 \mathrm{kPa}$

Displacement : $0.6732 \mathrm{~cm}$

最終形状（断面積一定）

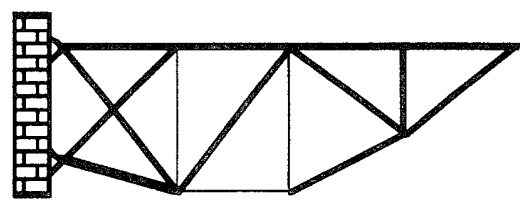

Fitness : 1.194

Total Mass : 0.837 ton

Max Stress : $147 \mathrm{kPa}$

Displacement : $0.6762 \mathrm{~cm}$

最終形状（断面積変化）

(Phase2）。次にそれまでに選ばれた節点の中の任意の3節点と選択可

能領域内の他の任意の節点により新しい四面体を構成する

(Phase3）。この過程を荷重を受ける節点と境界を受け持つ節点が全 て含まれるまで繰り返すことにより構造的に常に安定な立体トラスを 発生させることができる。

従来の方法である、部材の存在の有無を直接的にコーディングする 手法では、安定構造を発生させることは平面の場合と比べて格段に困 難であるが、ここで提案する手法によれば、初期発生、交叉、突然変 異のいずれの過程においても不安定な棈造や部材の重なりを持つ構造 は発生せず、GAによる形態発生を極めて効果的に行なうことができ る。図17に部材の最大沁力と荷重点での載荷方向の変位に制限を持 つ立体トラスの最小重量設計解を求める問題を解いた例を示す。図に は変位制限の值を変化させたときに生じる解形態の変化も併せて示し ている。

5.3 形状と位相の同時最適化解析

遺伝的アルゴリズムを用いてトラスの節点の移動を考慮して構造最

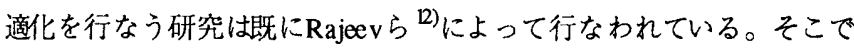
はトラスの断面積と節点の位置を变数として最適化を行なっており、 前述のように遺伝子上に直列に情報を配置して解析している。この考 え方は非常に素直であるものの、そこで扱われている9部材というシ ンプルな問題に対してすら大きな計算労力を要するものとなっている。 しかも、GAを用いているにも関わらず位相については4つのパターン を所与のものとして扱っており、改良すべき点は多い。

図18 に構造位相、部材断喕積、節点位置の3つの異なる情報を同時 に扱った場合の最小重量設計問題の解析結果を示している。図には比 較のために部材断面積を変化させず全て一定とした場合についての結 果と、断面積を $5 \mathrm{~cm}^{2} \sim 20 \mathrm{~cm}^{2}$ の間で変化させた場合の結果とを示して いる。解析途中の最適化過程の考察によれば、この種の最適化過程は まず位相があらかた決められ、節点位置（全体形状）と部材断面積は 互いにやりとりをくり返しながら次第に決まっていく様子が確認され ている。

6. まとめ

GA（遺伝的アルざバム）をトラスの位相最適化問題に用いるこ との種々の可能性について検討した。従来の方法では、不安定構造や 部材の重なりを除外する補助的な操作を必要とし、これが自由度を搪 げる際の大きな障害となっていたが、トラスの位相を安定した最小単 位（平面では三角形 立体では四面体）の構造体の集合として表現す ることによりこの問題を解決した。このことは同時に従来手がけられ ていなかった立体問題への搪張も可能にし、その解析例も示した。さ らに、ここで「多層型遺伝的アルゴリズム」と呼ぶ手法、すなわち位 相、寸法、形状の情報を、それぞれ独立に、並列するGA遺伝子群に 記述された情報としてとらえ、それらの重权合わせとしてトラス構造 を発生させる方法の採用により、従来のGAの解析限界を大幅に拡げ ることを可能にした。以下に本手法に関して現段階で残る問題点を2 点挙げておく。

図18: 構造位相、断面積、節点位置の同時最適 
1) 初期発生について：初期発生をできるだけ探索領域全体に離散させ ることが必要である。これはGAの持つ多様性を十分に発揮させるた めにも必要であり、実験計画法で用いられている直交座標系の考え方 を用いる方法などが考えられる。これはGA全般に関わる問題点であ る。

2) 探索領域について：GAは他の最適化手法と比較してはるかに高い探 索能力を持っている。なかでも突然変異の持つ威力は収束し始めた解 集合に対してもさらに別の探索対象解を扱うことができるようにする ことを自動的に行なうという、他の手法にはない独特の解析手段を提 供する。しかし、探索領域が広がると、世代数や人口のある条件下に おいて、同じような個体の連続的な発生により、やはり局所解に陥る 傾向が認められる。このような問題が生起する機構について明らかに しておく必要がある。

しかしながら、位相という離散的最適化変数を解析中に取り入れ、 さらに他の諸量をも考慮に入れることができる遺伝的アルゴリズムに よる構造最適化は、ここで示したような「多層化」のアイティアを通 して、さらにその可能性を大きくしたということができる。他にも、 いくつかの工夫（たとえば、適合度の評価を並列的に行なうなど）を 通して、今後少なくともしばらくは、この領域の解析手法として、最 も普遍的で強力な手段の一つであることは間違いないだろう。

\section{参考文献}

[1] Kirsch, U., Optimal Topologies of Structures, Applied Mechanics Review, Vol. 42, No. 8, pp. 223-239, 1989.

[2] Bendsoe, M. P., A. Ben-Tal, J. Zowe, Review Paper: Optimization Methods for Truss Geometry and Topology Design, Structural Optimization, Vol. 7, No. , pp. 141-159, 1994.

[3] Hagiwara, N., H. Ohmori, T. Matsui, Shape Optimization of Truss Structures by Stress Adjustment, Proceedings of Coceptual Design of Structures, International Symposium of IASS, University of Stuttgart, Vol. 1, No., pp. 238-245, 1996.

[4] Dorn, W. S., R. E. Gomory, H. J. Greenberg, Automatic Design of Optimal Structures, Journal de mecanique, Vol. 3, No. , pp. 25-52, 1964.

[5] Dobbs, M. W., L. P. Felton, Optimization of Truss Geometry, Journal of Structural Division, Proceedings of the American Society of Civil Engineers, Vol. 95, No. ST10, pp. 2105-2118, 1969.

[6] Suzuki, K., N. Kikuchi, A Homogenization Method for Shape and Topology Optimization, Computer Methods in Applied Mechanics and Engineering, Vol. 93, pp. 291-318, 1991.

[7] Bendsoe, M. P., N. Kikuchi, General Optimal Topologies in Structural Design using a Homogenization Method, Computer Methods in Applied Mechanics and Engineering, Vol. 71, pp. 197-224, 1988.

[8] Eschenauer, H. A., V. V. Kobelev, A. Schumacher, Bubble Method for Topology and Shape Optimization of Structures, Structural Optimization, Vol. 8, pp. 42-51, 1994.

[9] 伊能教夫, 小林弘樹, 下平真子,力学構造を自己組織化するセル . オートマトン（ローカルルールによって生じるシステム全体の 挙動）, 日本機会学会論文集（A編）, Vol. 61, No. 586, pp. 14161422(272-278), 1995.

[10] 中西康彦, 中桐 滋, 境界輪体によるトラスの位相最適化 (不適切 な構造を回避する設計変数の導出）, 日本機械学会論文集（A 編)，Vol. 61, No. 584, pp. 159-164, 1995.

[11] Goldberg, D. E., Genetic Algorithms in Search, Optimization and Machine Learning, Addison-Wesley Publishing Company, Inc., 1989.

[12] Rajeev, S., C. S. Krishnamoorthy, Genetic Algorithms-Based Methodologies for Design Optimization of Trusses, Journal of
Structural Engieering, Vol. 123, No. 3, pp. 350-358, 1997.

[13] 三井和男, 登坂宣好, 遺伝的アルコリズムの空間構造形態解析へ の応用, 日本建築学会構造系論文集, No. 484, pp. 75-82, 1996.

[14] Rajan, S. D., Sizing, Shape. and Topology Design Optimization of Trusses using Genetic Algorithm, Journal of Structural Engineering, Vol. 121, No. 10, pp. 1480-1487, 1995.

[15] Hajela, P., E. Lee, Genetic Algorithm in Truss Topological Optimization, International Journal of Solids and Structures, Vol. 32, No. 22, pp. 3341-3357, 1995

[16] Ohsaki, M., Genetic Algorithm for Topology Optimization of Trusses, Computers and Structures, Vol. 57, No. 2, pp. 219-225, 1995.

[17] Koumousis, V. K., P. G. Georgiou, Genetic Algorithms in Discrete Optimization of Steel Truss Roofs, Journal of Computing in Civil Engineering, Vol. 8, No. 3, pp. pp. 309-325, 1994.

[18] Sakamoto, J., J. Oda, A Technique of Optimal Layout Design for Truss Structures using Genetic Algorithm in 34th AIAA/ASME/ASCE/AHS/ ASC Structures, Structural Dynamics, and Meterials Conference AIAA/ ASME Adaptive Structures Forum, Lajolla, CA, , pp. 2402-2408, 1993.

[19] Ponslet, E., R. T. Haftka, H. H. Curney, Optimal Placement of Tuning Masses on Truss Structures by Genetic Algorithms in 34th AIAAV ASME/ASCE/AHS/ASC Structures, Structural Dynamics, and Meterials Conference AIAA/ASME Adaptive Structures Forum, Lajolla, CA, , pp. 2448-2457, 1993.

[20] Grierson, D. E., W. H. Pak, Optimal Sizing, Geometrical and Topological Design using a Genetic Algorithm, Structural Optimization, Vol. 6, pp. 151-159, 1993.

[21] 大崎純, 遺伝的アルコリズムに基づく不連続コスト関数を有する 構造物の最適設計法, 日本建築学会構造系論文集, No. 464, pp. 119-127, 1994 